\title{
The introduction of REITs and their impact on the leisure sector
}

Recerved (in revised form): 12 July 2005

\section{Mark Nichols}

is a senior tax partner at CMS Cameron MCKenna. He advises on all aspects of UK and international commercial tax matters, including both tax planning and transactional/ structuring advice. As well as M\&A, principal finance, private equity and joint venture work, Mark focuses on major property fund, investment and development work. Mark has a specialisation in stamp duty and, latterly, Stamp Duty Land Tax (SDLT) planning.

\section{Mike Boutell}

is a tax lawyer at CMS Cameron McKenna, and covers all aspects of corporate and commercial tax law with particular emphasis on property tax.

\begin{abstract}
A REIT is a real estate investment vehicle that is designed to allow an investor to replicate the returns received through owning property directly. The REIT was introduced in the USA in 1960 and is now available in most of the key developed countries. It is not yet available in the UK but, in March 2004, the government issued a consultation paper opening public debate on the form that a UK REIT might take, if introduced. Disappointingly, this suggested that hotels should be excluded as an asset class because a REIT should only be permitted to invest in property types where the rental returns reflect the underlying property asset. Thankfully, the government was persuaded by the argument that hotels should not be excluded and this was reflected in the March 2005 consultation paper. The government confirmed its aim in the 2005 Budget to legislate for UK REITs in the next year's Finance Bill, although there are a number of key issues that still need to be resolved. This paper takes a look at those issues of most importance to the leisure sector as well as those that could delay or even derail the introduction of the UK REIT.
\end{abstract}

\section{Keywords:}

REITs, consultation, tax transparency, hotel and leisure sector, withholding tax

\section{WHAT ARE REITS AND WHY ARE THEY SO POPULAR?}

Most industrialised countries have real estate investment trusts (REITs); the USA introduced the REIT in 1960 and most recently the French introduced the Sociétés d'investissements immobiliers 
cotées (SIIC), which has been available since 19 September 2003. The REIT also exists in the Netherlands, Italy and Belgium. Germany seemed set to introduce its own version but this now seems to be under some threat, coincidentally because it seems that it shares the same concerns about the taxation of non-residents as the UK (see below) and has so far been unable to resolve those concerns.

Although the detailed rules that exist in each country are different, the basic aims and attributes are similar. The REIT is designed to allow an investor to replicate the returns received through owning property directly. This is achieved by taxing the investors on the income received from the REIT and on the capital gains arising on a sale of their investment in the REIT; tax is not charged at the level of the REIT. Generally, commercial property is not an asset class that most individuals may invest in directly, and even for institutional investors the illiquid nature of property and high transaction costs reduces its attractiveness.

Investment in a REIT allows the investor to diversify his risk and spread his investment between assets that will produce an income stream and those that will provide capital appreciation. This should result in an increase in the capital flowing into the commercial property sector, which is one of the UK government's key objectives.

\section{THE UK REIT}

REITs could be highly beneficial to the hotel industry, but their attractiveness is dependent on how the government reacts to the views of industry during the consultation process. In May 2004 the authors' firm responded to the initial consultation process on behalf of the industry and was pleased that the majority of its proposals were included in the government consultation paper issued in March 2005. It is hoped that with continued industry support and ideas the same level of success can be achieved the next time round.

The government confirmed its aim in the 2005 Budget to legislate for UK REITs in the Finance Bill 2006. But this is still dependent on a number of key issues being satisfactorily resolved between the government and the real estate sector. The government requested comments on the second-stage consultation paper, and CMS Cameron McKenna, Jones Lang LaSalle Hotels and Hotel Analyst submitted a joint response on the remaining issues for hotels (which can apply equally for the wider leisure sector) after canvassing the views of some of those in the industry. ${ }^{1}$ This paper summarises below the key issues for the hotel sector and explains some of the thinking on those issues.

\section{ISSUES FOR THE LEISURE SECTOR}

Hotels and other leisure industry real estate assets (whether in the UK or outside) will be permitted REIT investments. In its first consultation paper, the UK government suggested that hotels 


\section{Structure for a hotel REIT}

\author{
75 per cent gross \\ income/gross assets \\ tests
}

Level of distributions should be excluded as an asset class because a REIT should only be permitted to invest in property types where the rental returns reflect the underlying property asset. In other words, REIT status should not be available unless the income from the hotel property asset could be separated from the income from the hotel business run from the hotel property asset.

As part of the representations put forward by CMS Cameron McKenna, Jones Lang LaSalle Hotels and Hotel Analyst, a model structure for a hotel REIT was suggested that would deal with the government's concerns. The model separates ownership of the property asset from that of the hotel business. The REIT would own the hotel while a separate taxable operating subsidiary would own the hotel business. In turn, the hotel business (which may be owned by a wholly owned subsidiary of the REIT) may enter into a management contract with an independent hotel operating company which would run the hotel.

The REIT would grant a lease or a licence of the property to the operating subsidiary. This lease or licence therefore achieves a separation of the income generated from the property asset (namely the rents received from the operating subsidiary under the lease or licence) from the income generated from the ownership of the hotel business (which would be subject to normal tax in the operating subsidiary). The government is protected from artificial inflation of the rent by the transfer pricing rules.

The government seems to have accepted this model and arguments, and now all property classes (but not derivatives) qualify to the extent that they produce rental income. Although the position is not entirely clear it is assumed that the rules will nevertheless permit turnover or other profit-geared leases.

The above structure will only be possible if the REIT can show that at least 75 per cent of its total gross income and at least 75 per cent of the gross value of its assets relate to property investment business. So for a REIT-owning hotel operating company it will have to demonstrate that the operating company is not worth more than 25 per cent of the totality of the REIT's assets. It is likely that most hotel REIT structures in the form set out above will or can qualify assuming no extreme valuation of intangibles, eg goodwill vested in the subsidiary.

A key point in relation to hotels is the question mark as to the level of distribution of profits required. The responses to the original consultation asked for 90 per cent. The government has now decided that there will be a requirement for a distribution by the REIT of at least 95 per cent of its real estate investment income after 'appropriate deductions and capital allowances'. There is concern within the hotel industry that a 95 per cent distribution requirement will leave many hotels with insufficient retained earnings to ensure that the fabric and contents of hotels continue to meet market and sector requirements. It is thought that in general repairs and reserves to cover depreciation and replacement of 


\section{Turnover/profit geared leases}

\section{Internal/external management}

\section{Investor risk}

\section{Listing}

furniture, fixtures and equipment (FF\&E) and capital items consumed in the operation of hotels will usually exceed the depreciation charge and a 5 per cent retention of earnings is unlikely to be sufficient to fund this gap adequately. It may be that it is this issue which distinguishes the hotel sector from the rest of the property industry and causes friction between the two. The hotel sector would be willing to work with the government on this issue, which is seen as fundamental to the likely success of the REIT in the sector.

There is no positive statement as to whether turnover or profitgeared leases will be permitted. It seems, from the absence of comment on the point, that they will be. Accordingly, the terms of the lease of a hotel, whether to a subsidiary or to a third party, can be on a proper market basis. Indeed, the lease will have to be on a market basis (in terms of rent value) as UK transfer pricing rules will be strictly applied to ensure that the REIT is only receiving an appropriate share of exempt rental income while any hotel management subsidiary achieves a sensible share of profits taxable in the UK on an ordinary basis.

Both internal and external management will be allowed in relation to REITs. This leaves the possibility for expert hotel groups and professionals to set up new hotel investment REITs, but also for particular hotel groups to look to the creation of more 'inhouse' REITs investing in hotels that are already familiar to them. This form of partial realisation of assets combined with ongoing asset management fees has already proved a popular model in the industrial property sector.

A REIT will not be permitted to invest in a single asset, and indeed any single property will not be entitled to exceed a defined proportion of the total value of the assets of the REIT. This requirement is presumably to limit the risk to the investor; the perception is that a REIT owning a portfolio of properties would carry less risk than one owning a single property. In general this might be right, but does investment in a REIT with a single flagship hotel carry more risk than investment in a REIT with a portfolio of unfashionable hotels in poor locations? More importantly, the rules need to cater for newly established REITs. While it is possible simply to have a REIT conversion or a REIT that acquires a portfolio, it is quite possible that a start-up REIT will gradually build up a portfolio of hotels. In its start-up period it may only own a small number of hotels. Indeed, in a portfolio purchase there may be one or two dominant hotels by value or size. The rules need to be flexible enough to extend REIT status to startups in the process of building a portfolio and to major developments with a long lead-in time, not only in the leisure sector but also in relation to, for example, shopping centres.

The government is still considering whether a REIT should be required to be listed or not. It is assumed that the hotel sector has no reason to deviate from the view of the general property sector in 


\section{Gearing}

\section{Conversion charge}

that area. But the proposal is not clear on the number of shareholders who must participate in a REIT, and there might be an issue again in relation to start-up REITs as to whether they need to be listed during an initial period. Further, professional investors may wish to consider REITs that are not in listed form.

It is noteworthy that REITs will not be permitted to invest in derivatives. It is possible to imagine that in a start-up situation the use of property or even hotel-specific derivatives may be a way to gain exposure to the hotel sector pending the acquisition of bricks and mortar.

It seems that the government wishes to impose a limit on the level of borrowing (primarily to avoid loss of tax for the Exchequer rather than to protect the retail investor!). The hotel sector will need to consider if a cap of, say, 40 per cent or 50 per cent would cause a problem. Although it is understood from previous discussions within the sector that a 50 per cent cap might not cause undue restriction on hotel REIT operations, the UK hotel and property sectors are well used to higher leverage already and that flexibility must be attractive. The general view within the industry is that there should be no restriction on the level of borrowing. It is difficult to see where the tax leakage arises. Interest paid to commercial lenders will fall to be taxed in their hands. If the concern were that lending arrangements would be put in place for the purpose of avoiding tax then surely it would be preferable for this to be countered by specific anti-avoidance rules.

The final key sector issue is in relation to the conversion charge. It seems that the government will use the conversion charge to neutralise any tax loss that it expects from compromises made on other measures in relation to REITs. Cynically it might be suggested that this will be a revenue raiser at just the time when the government coffers are in need of a boost. Setting a level of conversion charge is a difficult task, and the government will be engaged in ongoing talks with representatives of the real estate sector. The major difficulty that one sees in practice is that the government wishes to see REITs as a success and will have to take into account the fact that large groups, eg of hotel owners and perhaps other real estate groups, are able at the moment to sell large portfolios of assets such as hotels within a corporate wrapper and qualify for substantial shareholding relief. Accordingly, it is inconceivable that hotel groups with significant established businesses will be looking to convert the business into a REIT at the cost of any significant conversion tax, whether on capital gains or on a gross asset basis. Will the government understand this? Maybe. Will they be moved by it? Maybe not.

Unfortunately, in this area different taxpayers will have different views. Those taxpayers who can gather together assets with high base cost and put them into REITs will be happy to pay (or not pay) tax on the basis of capital gains. Those with very significant embedded capital gains will much prefer a lower rate of gross asset 


\section{Tax and the non-resident investor}

tax. Existing significant offshore unit trusts will surely not be attracted back on shore if there is an imposition of a (significant) gross-asset-based conversion tax. All that said and for what it is worth, it seems to the authors that the preferable route is some sort of deemed liability to Stamp Duty Land Tax (SDLT) to match the position of those newly set up REITs which would need to acquire properties from elsewhere.

\section{THE KEY TAX ISSUE}

Finally, readers should bear in mind that the major outstanding issue in relation to REITs is the treatment of distributions, particularly in a foreign context. Non-UK residents will be permitted to register as REITs, and thus there may be a difficulty in collection of tax from such REITs. Non-UK investors in UK REITs will be able to call for significant reductions in any withholding tax imposed on their dividends. The government is therefore in something of a quandary as to whether and how to deal with this. So serious is the issue that it seems to have threatened the German REIT process. On the other hand, the French authorities, in introducing their SIIC in the last couple of years, seem to have accepted the advantageous status available to non-French REIT companies and non-French investors in French REITs, although it is understood that the French government may have this issue under review. Again there will be a delicate balancing process between the desire to avoid the REIT being as big a failure as the little-known housing investment trust was some years ago and the desire of Gordon Brown to protect the Exchequer. There is undoubtedly a possibility that this issue could at least delay the 2006 start date. If this happens it is likely to be viewed by business generally as a lost opportunity.

A possible riposte to the tax protectionist argument is that at the moment the UK property and hotel sector attracts a large number of offshore investors who, through high leverage and non-resident status, pay little or no UK tax on their rental or capital return. REITs may in fact have the effect of reducing that imbalance by bringing more UK investors into the market and should also increase the SDLT take through increased liquidity. Yet the hotel industry must be prepared to accept a lower gearing limit to ensure more distributions to investors.

All in all, there are interesting times ahead in relation to the REIT debate and the next few months will be key in relation to the final decision as to whether a REIT will be introduced and its attractiveness to the leisure sector and indeed more widely.

\section{Note}

1. Readers who would like a copy of the joint response or have views or useful information should feel free to contact Mark Nichols at mark.nıchols $a$ cms-cmck com. 